\title{
PAIN CHARACTERIZATION IN INSTITUTIONALIZED ELDERLY PATIENTS
}

\author{
Luciana Araújo dos Reis', Gilson de Vasconcelos Torres ${ }^{2}$, Luana Araújo dos Reis ${ }^{3}$
}

\begin{abstract}
The aim of the present study was to identify the prevalence and characteristics of pain chronic in relation to qualitative aspects and location in elderly (65 the 104 old) institutionalized in Jequie, Bahia, Brazil. This is a descriptive exploratory study with a transversal design and quantitative approach. The instrument used consisted of: data identification; mini-mental examination; pain-related aspects; and the McGill Pain Questionnaire. Half of the subjects were women, with a pain prevalence of $73.3 \%, 30 \%$ of whom had experienced pain for 1 to 5 years, $25 \%$ for more than 5 years, $28.3 \%$ did not cite pain duration and $16.6 \%$ reported having had pain for less than 1 year. With respect to quantification of pain, the most cited was moderate $(25.7 \%)$. Many of the elderly were in the age group of 60 to 69 years, most painful complaint lodged mild and moderate, and places most affected were, knees and lumbar spine.
\end{abstract}

KEY WORDS: elderly, pain, prevalence, quality of life.

\section{Características de dor em pacientes idosos institucionalizados}

Resumo - O presente estudo teve por objetivo identificar a prevalência e características da dor crônica, quanto aos aspectos qualitativos e localização em idosos (65 a 104 anos) institucionalizados no município de Jequié/BA. Trata-se de pesquisa de caráter exploratório descritivo com delineamento transversal e abordagem quantitativa. $O$ instrumento utilizado foi constituído de: dados de identificação; mini-mental; aspectos relacionados à dor; e Questionário de dor de McGill. Quanto ao sexo $50 \%$ era feminino, com prevalência de dor de $73,3 \%$. 30\% sente dor no intervalo de 1 a 5 anos, $25 \%$ há mais de 5 anos, $28,3 \%$ não citou e $16,6 \%$ tempo menor que 1 ano. Quanto à quantificação da dor, a mais citada foi a moderada, $25,7 \%$. Grande parte dos idosos se encontrava na faixa etária de 60 a 69 anos, a maioria apresentou queixa dolorosa leve e moderada e os locais mais acometidos foram, joelhos e coluna lombar.

PALAVRAS-CHAVE: idosos, dor, prevalência, qualidade de vida.

The growth in world population tends to confirm the projections of the World Health Organization in the year 2000 that there would be 585 million elderly individuals in the world'. The projections show that all ages will increase by $73 \%$, those between 60 and 80 years by $91 \%$ and individuals older than 80 years by $119 \%$. In Brazil, the projections in $\mathbf{2 0 0 0}$ were that the elderly population would reach 14 million and in the year 2025 this figure would be 30 million, which corresponds to $10 \%$ of the population ${ }^{1-2}$. According to Davim ${ }^{3}$ as individuals age, they tend to feel progressively fragile and abandoned, not only by the family, but by society itself. Since they are often seen as unproductive, they are not always welcomed by the fami- ly and are obliged to live in nursing homes or shelters for the elderly. Nursing homes are usually inappropriate for the needs of the elderly, compromising the interpersonal relationships that are indispensable to their lives ${ }^{4}$. Moreover, because these institutions tend to promote isolation and physical and mental inactivity, there are negative consequences for health ${ }^{5}$.

The aging process is not usually characterized as a healthy period or one of independence. In contrast, it is characterized by a high incidence of chronic and degenerative diseases, which often result in increased dependence. Many of these situations are accompanied by pain, and in a significant number of them chronic pain is the in-

FAPESB (Foundation of Support and research of the State of Bahia, Brazil): 'Physical therapist, Specialist in Public Health, Professor in the Department of Health of the State University of the Southeast of Bahia (UESB), Brazil, Masters student in the Postgraduate Program of Health Sciences (PPGCSa) at the Federal University of Rio Grande do Norte (UFRN), Natal, Brazil; ${ }^{2}$ Nurse, Doctorate in Nursing from the School of Nursing of Riberão Preto (EERP) of the University of São Paulo (USP), Professor in the PPGCSa at UFRN, Study advisor; ${ }^{3}$ Undergraduate student in the course of Nursing at the Faculty of Technology and Sciences (FTC), Bahia, Brazil.

Received 19 February 2008, received in final form 15 April 2008. Accepted 2 May 2008. 
dividual's main complaint, a fact that may interfere in the quality of life of the elderly ${ }^{6}$.

Pain, as defined by the International Association for the Study of Pain (IASP), is an unpleasant sensory and emotional experience that is described in terms of real or potential tissue lesions ${ }^{7}$. Pain can be classified as acute or chronic. Acute pain is associated to an acute pathological process or traumatic lesion, and usually persists until the healing process establishes itself. It has a warning function and is associated to neurovegetative alterations ${ }^{7,8}$. Chronic pain is defined as that which persists beyond the reasonable lesion healing time. It may also be associated to chronic pathological processes that cause continuous or recurring pain over months or years ${ }^{8}$. Pain has been reported in some studies as one of the factors that most interferes with the health status of the elderly. The prevalence estimates range from $25 \%$ to $50 \%$ of the elderly population who live in the community and between $45 \%$ to $80 \%$ of nursing home residents ${ }^{9,10}$. Recent studies" show a decrease in hyperalgesic activity, in experimental animals administered mononuclear leukocytes from healthy elderly individuals, when compared to receiving those of young adults. The decrease in interleukin 2, an important inflammatory mediator present in the blood of elderly persons, may have contributed to these findings. Moreover, an unsuitable approach to this problem could have a significant impact on the quality of life of the elderly, leading to depression, aggressiveness, social isolation and diminished function". Pain is one of the causes of increased morbidity in the elderly. Literature data ${ }^{10}$ point to a greater pain prevalence in the elderly than in other phases of life.

Thus, the aim of this study was to identify the prevalence and characteristics of pain, with respect to qualitative and quantitative aspects as well as location in institutionalized elderly patients in Jequié, Brazil.

\section{METHOD}

This is a descriptive exploratory study with a transversal design and quantitative approach. The study was conducted at the Fundação Leur Britto, it is an institution that exclusively houses the elderly population of Jequié, Bahia and also since it serves as a training facility for physical therapy and nursing students from the State University of the Southeast of Bahia (UESB).

The population of the study was composed of all elderly residents in the institution cited in the proposed period for collecting data. As the criterion for exclusion, the elderly who do not have mental conditions to meet the roadmap, which did not wish to interview and voluntarily participate in the study. To assess the state mental (cognitive conditions) of the elderly was used the Mini-examination of the mental state - MMSE (Mini-mental)' The MMSE is composed of 30 issues categorical, and the guest is as follows: 30 to 26 points (preserved cognitive functions), 26 to 24 points (amendment not suggestive of deficit) and 23 points or less (suggestive of cognitive deficit). For inclusion in the study were selected that showed the elderly above 23 points. From a total of 68 elderly residents in the institution 8 were excluded because they presented a MMSE score of less than 24 points.

60 elderly were included, 30 of each sex, $40 \%$ had preserved cognitive functions and $60 \%$ showed a change not suggestive of cognitive deficit.

The instrument used for data collection consisted of four parts: the first part collected identification data; the second part was the MMSE; the third part comprised pain-related aspects; and the fourth part the McGill Pain Questionnaire.

The McGill Pain Questionnaire consists of a list of words that describe pain. It assesses, discriminates and measures the various dimensions of the pain experience and is composed of 78 descriptors organized into 4 large groups with 20 subgroups. These subgroups describe the sensory component ( groups 1 to 10), which involves temporal-spatial, mechanical, thermal and pain anxiety aspects; the affective (11 to 15), involving tension, fear, self-punishment and neurovegetative responses; the evaluative (16), which reflects the assessment of the overall situation and represents a judgment based on the sensory and affective characteristics of the patient's previous experience and on the meaning of the situation; and the miscellaneous (17 to 20). The patient's choice of descriptors provides two measures: the pain index, which is a sum of the intensity values of the descriptors selected and the number of descriptors chosen. This protocol also contains the drawing of a human figure, seen from the front and from the back, so that the individual can better identify the location of the pain?

The summations McGill Pain Questionnaire are divided into mild, moderate and intense, taking into consideration sensory, affective, and miscelaneous assessment. In group sensory, pain is classified as mild ( 0 to 14 ), moderate (14 to 28 ) and intensive ( 28 to 42 ), the group affective in mild ( 0 to 4$)$, moderate ( 4 to 9) and intensive ( 9 to 14 ), the group affective in mild (0 to 4 ), moderate (4 to 9) and intensive (9 to 14), the group evaluative in mild ( 0 to 1 ), moderate ( 1 to 3 ) and intensive ( 3 to 5 ), and the group miscelâneo in mild ( 0 to 2$)$, moderate (5 to 11$)$ and intensive (11 to 17).

The collection procedures were approved by the Research Ethics Committee of the Federal University of Rio Grande do Norte (UFRN), according to resolution 196/96 for studies conducted with human beings. The elderly patients or their legal guardians signed an informed consent form.

Inferential statistical analyses were applied using Statistical Analysis System (SAS) software. Kruskal-Wallis test was used to analyze the number and sum of the McGill verbal descriptor indices. All data analysis was submitted to statistical review to decide the appropriate tests to be used. The subjects were characterized by descriptive statistics. The presence of pain for the last year was used as the parameter for calculating its prevalence. 
Table 1. Distribution of the elderly patients according to sex, age group, income, occupation and length of time years institutionalized. Jequié, Brazil, 2006.

\begin{tabular}{|c|c|c|c|c|c|c|c|}
\hline \multicolumn{2}{|c|}{ Sociodemographic variables } & \multicolumn{4}{|c|}{ Sex } & & \\
\hline & & \multicolumn{2}{|c|}{ Male } & \multicolumn{2}{|c|}{ Female } & \multicolumn{2}{|c|}{ Total } \\
\hline & & $\mathrm{n}$ & $\%$ & $\mathrm{n}$ & $\%$ & $\mathrm{n}$ & $\%$ \\
\hline \multirow[t]{2}{*}{ Age group (in years) } & 60 to 80 & 20 & 33.4 & 15 & 25.0 & 45 & 58.4 \\
\hline & Older than 80 & 10 & 16.6 & 15 & 25.0 & 15 & 41.7 \\
\hline \multirow[t]{2}{*}{ Schooling } & Illiterate & 23 & 38.3 & 22 & 36.7 & 45 & 75.0 \\
\hline & Elementary education & 7 & 28.3 & 8 & 13.4 & 15 & 25.0 \\
\hline Income & $\begin{array}{l}1 \text { minimum monthly } \\
\text { wage ( } \approx \text { US\$210.00) }\end{array}$ & 30 & 50.0 & 30 & 50.0 & 60 & 100 \\
\hline \multicolumn{7}{|l|}{ Current activity } & 100 \\
\hline Length of time & 1 to 10 years & 25 & 41.6 & 25 & 41.6 & 50 & 83.2 \\
\hline \multirow[t]{2}{*}{ institutionalized } & More than 10 years & 5 & 8.4 & 5 & 8.4 & 10 & 16.8 \\
\hline & Total & 30 & 50.0 & 30 & 50.0 & 60 & 100 \\
\hline
\end{tabular}

Table 2. Distribution of pain intensity by group, Jequié, Brazil, 2006.

\begin{tabular}{lccc}
\hline & Light & Moderate & Intense \\
\hline Sensory & $54.60 \%$ & $34.10 \%$ & $11.30 \%$ \\
Affective & $40.90 \%$ & $40.90 \%$ & $18.20 \%$ \\
Evaluative & $56.80 \%$ & $15.90 \%$ & $27.30 \%$ \\
Miscellaneous & $56.80 \%$ & $29.60 \%$ & $13.60 \%$ \\
Total & $52.30 \%$ & $34.10 \%$ & $13.60 \%$ \\
\hline
\end{tabular}

\section{RESULTS}

We studied 60 elderly institutionalized, and $50 \%$ each sex, often with males in the age group 60 to 80 years (33.3\%). Minimum age was 60 years, maximum 104, average 77.6 years and standard deviation 11.64

Table 1 shows a greater frequency of elderly men in the 60 -to-80-year age group responding to $58.4 \%$ of the total (33.4\% men and $25 \%$ women). This was followed by the over 80 year-olds, where women had a higher frequency (25\%).

With respect to schooling, two categories were included, owing to the low number of individuals with elementary or secondary education. Forty-five $(75 \%)$ of the elderly are illiterate [23 (38.3\%) men and 22 (36.7\%) women] and only 15 (25\%) are literate. These results show that illiteracy was roughly equal between the sexes.

In regard to income, both sexes earned 1 minimum monthly wage ( $\approx$ US\$210.00) from retirement/old age pensions.

Most of the subjects ( $50=83.2 \%$ ) have lived at the nursing home for between 1 and 10 years and 10 (13.3\%) have been institutionalized for more than 10 years.

The data in this study show that $40 \%$ of the individuals had preserved cognitive functions and $60 \%$ had some alteration non-suggestive of deficit. This alteration was predominantly in the 60-to-80-year age group, with no difference between the sexes.

The presence of pain was analyzed qualitatively and described by degree, as shown in Table 2.

Pain intensity was divided into light, moderate and intense, taking into account the sensory, affective, evaluative and miscellaneous groups. In the sensory group, pain was classified as light ( 0 to 14), moderate (14 to 28) and intense (28 to 42 ); in the affective group as light (0 to 4$)$, moderate ( 4 to 9) and intense ( 9 to 14); in the evaluative group as light ( 0 to 1 ), moderate ( 1 to 3 ) and intense ( 3 to 5 ); in the miscellaneous group as light ( 0 to 2 ), moderate (5 to 11) and intense (11 to 17).

In the total distribution of the sums, a higher prevalence was found for light pain (52.3\%), followed by moderate pain (34.1\%).

The most frequent McGill descriptors in the elderly were: in the sensory group, shooting and stabbing, affective group, annoying and unbearable, evaluative group, miserable and nauseating and miscellaneous group, tiresome and tightening. There was greater prevalence of descriptors in the sensory group, with a mean of 6.5 , followed by the affective group (3.1).

The results show that $37(84 \%)$ of the elderly patients who experienced pain used no medication to relieve it, whereas 7 (16\%) used the painkiller.

Of the 60 elderly individuals studied, most (44=73.3\%) experienced pain, with a slight prevalence among the men $(23=38.3 \%)$, compared to the women $(21=35 \%)$, while those who had no pain represented $26.6 \%$ of the total. It was also found that $52.3 \%$ of elderly individuals with pain were in the 60 -to-80-year age group and that $75 \%$ of the subjects with no pain were from that same group. 
Table 3. The presence of pain according to sex, age group, length of time institutionalized and mental state. Jequié, Brazil, 2006.

\begin{tabular}{|c|c|c|c|c|c|c|c|c|}
\hline & & \multicolumn{4}{|c|}{ Presence of pain } & & & \multirow[t]{3}{*}{$\mathrm{p}$} \\
\hline & & \multicolumn{2}{|c|}{ Yes } & \multicolumn{2}{|c|}{ No } & \multicolumn{2}{|c|}{ Total } & \\
\hline & & $\mathrm{n}$ & $\%$ & $\mathrm{n}$ & $\%$ & $\mathrm{n}$ & $\%$ & \\
\hline \multirow[t]{2}{*}{ Sex } & Male & 23 & 38.3 & 7 & 11.6 & 30 & 50.0 & 0.573 \\
\hline & Female & 21 & 35.0 & 9 & 15.0 & 30 & 50.0 & \\
\hline \multirow[t]{2}{*}{ Age group } & 60 to 80 years & 23 & 38.3 & 12 & 20.0 & 35 & 58.4 & 0.161 \\
\hline & $>80$ years & 21 & 35.0 & 4 & 6.6 & 25 & 41.6 & \\
\hline Length of time & 1 to 10 years & 40 & 66.6 & 11 & 18.3 & 51 & 85.0 & 0.897 \\
\hline institutionalized & $>10$ years & 4 & 6.6 & 5 & 8.3 & 9 & 15.0 & \\
\hline \multirow{2}{*}{ Mental state } & Preserved cognition & 14 & 23.3 & 10 & 16.6 & 24 & 40.0 & 0.006 \\
\hline & Altered cognition & 30 & 50.0 & 6 & 10.0 & 36 & 60.0 & \\
\hline \multirow[t]{4}{*}{ Location } & Not cited & 2 & 2.8 & 14 & 19.7 & 16 & 22.5 & 0.0 \\
\hline & UL & 10 & 14.1 & -- & -- & 10 & 14.1 & \\
\hline & $\mathrm{LL}$ & 20 & 28.2 & 1 & 1.4 & 21 & 29.6 & \\
\hline & Back & 22 & 31 & 2 & 2.8 & 24 & 33.8 & \\
\hline \multirow[t]{2}{*}{ Intensity } & No Pain & 2 & 2.8 & 14 & 19.7 & 16 & 22.5 & 0.0 \\
\hline & Pain & 52 & 73.2 & 3 & 4.2 & 55 & 77.4 & \\
\hline \multirow[t]{2}{*}{ Pathology } & None & 1 & 1.4 & 10 & 14.1 & 11 & 15.5 & 0.0 \\
\hline & Osteomuscular disorders & 41 & 57.7 & 4 & 5.6 & 45 & 63.3 & \\
\hline
\end{tabular}

UL, upper limbs; LL, lower limbs.

With respect to length of time institutionalized, $90.1 \%$ of the elderly with pain had been institutionalized between 1 and 10 years, while $68.7 \%$ of those without pain had been nursing home residents for the same time interval. A total of $68.2 \%$ with pain had cognitive alteration not suggestive of deficit, whereas $62.5 \%$ without pain had preserved cognitive functions.

In the distribution of pain according to location, there was a greater concentration of back pain ( $22=31 \%$ ), followed by the lower limbs (LL) $(20=28.2 \%)$ and the upper limbs (UL) $(10=14.1 \%)$. Severe was the most frequently reported pain intensity (61.4\%). In regard to pain duration there was a higher incidence in the 1 to 5 -year interval (63.6\%).

We can therefore state, according to the $p$-value shown in Table 3, that sex $(p=0.573)$, age group $(p=0.161)$ and length of time institutionalized $(p=0.897)$ do not influence the presence of pain in the elderly. The factor that increases the presence of pain is mental state $(p=0.006)$, pain location $(p=0.0)$, pain intensity $(p=0.0)$ and pathology $(p=0.0)$.

\section{DISCUSSION}

The present study assessed the prevalence of pain in a population of 60 elderly individuals. The predominant age group was between 60 and 69 years (41.7\%), divided equally between the sexes. The distribution of the age groups was in accordance with the national reality, but the distribution according to sex does not reflect Brazilian reality, since women are more numerous in the over-60 age group'.
The low schooling levels of most of the subjects, where $66.6 \%$ (44) were illiterate, shows the need for education measures in the health area to instill greater understanding and motivation in these elderly individuals, given that some characteristics such as illiteracy, retirement and altered nutritional states lead to greater degrees of dependence on others ${ }^{12}$.

All of the subjects have an income of 1 minimum monthly wage ( $\approx$ US\$210.00). In a study carried out in São Paulo it was found that $70 \%$ of the elderly have monthly incomes of US\$100.00, characterized as low income ${ }^{13}$.

The findings of this study are similar to those found in the literature, since $73.3 \%$ of the elderly reported the presence of pain. A study involving 100 institutionalized elderly patients, which used the same criterion to define chronic pain as that used in this study, found chronic pain in $66 \%$ of these individuals ${ }^{14}$.

Chronic pain is the main ambulatory complaint among the elderly and the most frequent symptom recorded on medical charts, occurring in $25 \%-50 \%$ of patients. Between $45 \%$ and $80 \%$ of elderly institutionalized individuals experience at least one type of pain, and in $34 \%$ of these cases the symptoms are continuous ${ }^{15}$.

Pain has been cited in studies as one of the factors that most interferes in the health of elderly people. The estimates range from $25 \%$ to $50 \%$ of the elderly population that lives in the community and between $45 \%$ and $80 \%$ of nursing home residents ${ }^{16}$. A number of studies found that 
health complaints reach their peak in middle age and then decrease. Others report a correlation between the prevalence of persistent pain and increased age ${ }^{9,10}$.

In this study, $60 \%$ had some cognitive alteration not suggestive of deficit. In a study with 18,056 adults from various cities of the United States, lower scores were found in elderly individuals over the age of $80^{11}$.

In the current study the presence of pain was reported for between 1 and 5 years by $40.9 \%$ and for more than 5 years by $36.4 \%$ and was classified as light by $52 \%$ of the subjects. Data corroborated those with study in which, 123 elderly women, $43.1 \%$ reported having moderate to severe pain and $36.6 \%$ of these suffered limitations in their daily activities ${ }^{17}$. Another study that assessed 990 individuals over the age of 65 years found that around $20 \%$ of them complained of frequent pain (daily or once or twice per month) ${ }^{18}$.

The most frequent pain sites were the lower back, this study right hip/thigh, knees and legs. In an epidemiological study on musculoskeletal pain, 258 persons between the ages of 55 and 74 were studied to assess the relation of hip and knee pain with other morbid conditions and incapacity. Among the 124 individuals with associated morbidity, $10.8 \%$ had hip, knee and back pain ${ }^{19}$.

Similar results were found in a search with 3094 elderly persons living in the community, $32.5 \%$ were found with concomitant pain in the lower limbs and the dorsal region ${ }^{18}$. Another study with 100 elderly community residents reported joint pain in $50 \%$, back pain in $40 \%$ to $50 \%$ and lower limb pain in $38 \%$ to $50 \%$. The highest pain prevalence of lower limb pain was in those older than 85 years $^{20}$.

In conclusion, a large number of the institutionalized elderly patients are in the 60-to-69-year age group; most of the elderly had pain complaints, classified as mainly light or moderate; the most affected pain sites were the right and left knees, the right leg and the lower back.

\section{REFERENCES}

1. Garcia RA, Carvalho JAM. O envelhecimento da população brasileira: um enfoque demográfico. Cad Saúde Pública 2003;19:725-733.

2. Sousa L, Galante H, Figueiredo D. Qualidade de vidas e bem-estar dos idosos: um estudo exploratório na população portuguesa. Rev Saúde Pública 2003;37:364-371.

3. Davim RMB, Torres GV, Dantas SMM, Lima VM. Estudo com idosos de instituições asilares no município de Natal/ RN: características socioeconômicas e de saúde. Rev Latino-americana Enfermagem 2004; 12:518-524.

4. Yamamoto A, Diogo MJDE. Os idosos e as instituições asilares no município de campinas. Rev Latino-americana Enfermagem 2002;55:568-574.

5. Silva ANA, Santa Clara NS. Perfil dos idosos institucionalizados e prevalência de dependência em uma instituição de longa permanência da cidade de Caratinga - MG. Caratinga, FUNEC 2003.

6. Freitas MC, Maruyama SAT, Ferreira TF, Mota AMA. Perspectivas das pesquisas em gerontologia e geriatria: revisão de literatura. Rev Latino-amer Enfermagem 2002;10:221-228.

7. Ferrell BR, Ferrell BA (Eds). Pain in the elderly: a report of the task force on pain in the elderly of the International Asociation for-the Study of Pain. Seattle: IASP. Press, 1996.

8. Ferrell BA. Pain management in elderly people. J Am Geratr Soc 1991; 39:64-73.

9. Gagliese L, Melzack R. Chronic pain in elderly people. Pain 1997; 70:3-14.

10. Parmelle PA, Smith B, Katz IR. Pain complaints and cognitive status among elderly institution residents. J Am Geriatr Soc 1993;41:517-522.

11. Helme RD, Gibson SJ. Pain in the elderly. In: Jensen TS, Turner JA, Wiesenfeld-Hallin Z (eds). Proceedings of the $8^{\text {th }}$ World Congress on Pain (Progress in pain research and management). Seattle: IASP Press, 1997; 8:919-944.

12. Giatti L, Barreto SM, Lima MFC. Condições de saúde, capacidade funcional, uso de serviços de saúde e gastos com medicamentos da população idosa brasileira: um estudo descritivo baseado na Pesquisa Nacional por Amostra de Domićlios. Cad Saúde Pública 2003;19:735-743.

13. Stein LM, Argimon IL. Habilidades cognitivas em indivíduos muito idosos: estudo longitudinal. Cad Saúde Pública 2005;21:17-25.

14. Augusto ACC, Soares CPSS, Resende MA, Pereira LSM. Avaliação da dor em idosos com doença de Alzheimer: uma revisão bibliográfica. Textos Envelhecimento 2004;7:21-25.

15. Amero P, Muriel C, Santos JFJ, Rodrigues RE, Gonzalez RS. Bases genéticas del dolor. Rev Soc Esp Dolor 2004;11:444-451.

16. Pimenta CAM, Teixeira MJ. Avaliação da dor. Rev Médica São Paulo 1997;76:27-35.

17. Teixeira MJ. Síndromes dolorosas. Rev Médica São Paulo 1997;76: 21-26.

18. Magni G, Marchetti M, Moreschi C. Chronic musculoskeletal pain and depressive symptoms in the National Health and Nutrition Examination: I. Epidemiologic follow-up study. Pain 1993;53:163-168.

19. Birse TM, Lander J. Prevalence de chronic pain. Can J Public Health 1998;89:129-131.

20. Klinger LM, Spauding OT, Sandi J, Palatajko H, Mackinnon JR, Miller L. Chronic pain in the elderly: occupational. Clin J Pain 1999;15:275-283. 